\title{
Andrena florea FABRICIUS, 1793 (Hymenoptera, Apoidea, Apiformes): a rare bee species in Poland, related to the expansion of the alien plant Bryonia dioica JACQ. (Cucurbitaceae)
}

\author{
JÓZEF BANASZAK ${ }^{1}$, LUCYNA TWERD ${ }^{1}$, HALINA RATYŃSKA ${ }^{1}$, \\ WERONIKA BANASZAK-CIBICKA ${ }^{2 *}$, TERESA ZYŚ ${ }^{1}$ \\ ${ }^{1}$ Institute of Environmental Biology, Kazimierz Wielki University, Ossolińskich 12, \\ 85-093 Bydgoszcz, Poland \\ ${ }^{2}$ Institute of Zoology, Poznań University of Life Sciences, Wojska Polskiego 71C, \\ 60-625 Poznań, Poland
}

\begin{abstract}
Although research into alien species usually focuses on their negative aspects associated with their penetration into native ecosystems, their influence is much more complicated. This study investigated the pollinators of Bryonia dioica, an invasive climber in the temperate zone. Flowers of this plant in two cities in western Poland (Bydgoszcz and Poznań) were visited by 27 bee species, the most frequent ones being Apis mellifera and Andrena florea. Until recently, the latter was regarded as rare and threatened in Poland. Our results indicate that the spread of Bryonia dioica into urban areas has enabled large and stable populations of Andrena florea to flourish there. This study investigated the daily and seasonal dynamics of its activity. A positive relationship was found between the spread of Bryonia dioica and the presence of its obligatory pollinator Andrena florea. Alien plant species are thus not only an additional source of food for local pollinators but also may favour the occurrence of otherwise rare species with specific food requirements, such as A. florea.
\end{abstract}

KEY WORDS: Andrena florea, Bryonia dioica, alien species, oligolectic bee, Poland, cities.

\footnotetext{
*Corresponding author: banaszak@up.poznan.pl
} 


\section{INTRODUCTION}

The spread of species of flora and fauna outside their natural distribution ranges poses many threats to native ecosystems (BAX et al. 2003, LEVINE et al. 2003, MOROŃ et al. 2009, VILÀ et al. 2010, PISANTY \& MANDELIK 2012). This phenomenon, often in the form of invasion, is currently one of the major problems of nature conservation, besides landscape fragmentation and the loss of natural habitats (BARTOMEUS et al. 2008). The intentional or accidental introduction of alien species into the environment significantly affects the structure and functioning of ecosystems and may threaten global biodiversity.

From the ecological and economic standpoint, the interactions between plants and the insects that pollinate them, like bees, are particularly important. These relationships are analysed both separately (TRAVESET \& RiCHARDSON 2006, MATTESON et al. 2008) and as whole networks of relationships (BARTOMEus et al. 2008, MONTERO-CASTAÑo \& VILÁ 2012), and concern the influence of alien plant species and alien pollinators. Those taxa form new networks of interactions with native species, and their influence is not always unambiguously negative (TRAVESET \& RICHARDSON 2006, BARTOMEUS et al. 2008, DAVIS 2009). These examples relate mostly to plants used in agriculture, horticulture or for recreation, which adapt to the new environment but do not damage ecosystems (EwEL et al. 1999). Research on invasion ecology usually focuses on the negative effects of alien species, while potential positive effects often go unnoticed. Although introductions of alien species can benefit native biota, ecological studies often overlook potential beneficial interactions. An understanding of all the interactions between alien and native species may thus have important consequences for ecological management and nature conservation (GOODENOUGH 2010, DUDEK et al. 2016).

Towns and cities are special habitats, in which alien species can play a significant role. Urban areas are relatively new ecological spaces, where to a large extent the flora is intentionally shaped by human activity; this undoubtedly enriches the food resources in those areas. Moreover, urban habitats have a specific climate with higher air temperatures than in surrounding areas. Urban environments also affect other parameters, like solar radiation, wind speed, precipitation and cloud cover, air and soil pollution, salinity, alien soils and water deficits (JACKOWIAK 1990, SANTAMOURIS 2013). All these environmental changes may ultimately provide opportunities for development that cannot be found elsewhere. The specific urban conditions may favour the colonization of cities by alien species with higher temperature requirements.

Like Bryonia alba L., B. dioica JACQ. is an invasive species in temperate climate regions of the world. $B$. alba has a distribution from central Europe to Kazakhstan, $B$. dioica throughout western Europe and into north Africa. Changes in the distribution ranges 
of Bryonia L. species have mostly been caused by human activity, as these plants have been used as medicines and ornamentals for more than two millennia (RENNER \& SCHAEFER 2008). At the same time, researchers in western Europe have observed a gradual increase in the number of localities of a previously very rare bee species, Andrena florea FABRICIUS, 1793 (SCHRÖDER \& LUNAU 2001, AYASSE et al. 2015, VENNE 2015), which they consider to be linked with the spread of its forage plant, Bryonia dioica. Such an increase has also taken place in Poland. The present study thus investigated interactions between the pollinator Andrena florea and the bee forage plant Bryonia dioica, in order to address the following questions: (1) To what extent does the expansion of B. dioica affect the spread of Andrena florea? (2) What is the contribution of A. florea to the total number of pollinators of Bryonia dioica? (3) To what extent do environmental conditions affect the daily and seasonal activities of Andrena florea?

\section{MATERIALS AND METHODS}

\section{Study organisms}

Andrena florea is a Pontic-Mediterranean species, until recently classified in Poland as endangered (BANASZAK 2004). This bee is associated with its forage plants of the genus Bryonia, e.g. B. dioica and B. alba, although males have also been observed on other flowering plants (KOCOUREK 1989). Andrena florea builds its well-masked nests in the ground; entry to them is gained only through a small hole.

The distribution of A. florea ranges primarily from western Europe to southern England and the northern coasts of Africa. In the east, it has scattered localities in e.g. Asia Minor (GUSENLEITNER \& SCHWARZ 2002). Before 2000 it was regarded as very rare in Poland, recorded only locally (BRISCHKE 1888, DITRICH 1903, ŁOZIŃSKI 1920). It is widespread in the warm parts of Europe and quite frequent in some areas, but its density is usually low.

The genus Bryonia belongs to the family Cucurbitaceae. Only two of its numerous species (12) found in Eurasia, north Africa and the Canary Islands have been recorded in Poland: B. alba and B. dioica. Both are perennials (hemicryptophytes), climbers with curling tendrils. Having no supportive tissue, Bryonia spp. climb to heights of 3-4 m on trees, shrubs and fences. The leaves are relatively large, palmately lobed (5 lobes). They flower in June and July, and their fruits are berries. The plants are poisonous. In Europe, they have been grown in gardens because of their ornamental and medicinal value; currently, as naturalized plants, they are classified as kenophytes (SUDNIK-WÓJCIKOWSKA \& KoźNIEWSKA 1988, RENNER \& SCHAEFER 2008). They are found in thickets, along roadsides, and B. alba is a characteristic species of the tall herb community Sicyo- 
Echinocystietum FIJAŁKOWSKI 1978 ex BRZEG et M. WOJTERSKA 2001 (RATYŃSKA et al. 2010).

White bryony, Bryonia dioica, has small, greenish-white flowers. Abundant nectar is secreted to the concave receptacle (LIPIŃSKI 2010). Its fruits are rounded berries, 5-8 mm across, initially green, then turning orange and red, and are dispersed by birds. In the wild it is known from south-western Europe and Denmark; it is very common in many parts of England. First recorded in Poland in 1874 (TOKARSKA-GUZIK et al. 2012), it is currently reported from a small number of scattered localities all over the country (ZAJĄC \& ZAJĄC 2001) (Fig. 1).

\section{Methods}

The main study area was the city of Bydgoszcz (NW Poland) (Fig. 2). The spread of Andrena florea, compared to the expansion of Bryonia dioica in Poland and in Bydgoszcz, was analysed on the basis of published data (BRISCHKE 1888, DITRICH 1903, ŁOZIŃSKI 1920, KOWALCZYK et al. 2004) and original research.

Research on the distribution of localities of B. dioica and the taxonomic composition of Apiformes pollinating its flowers in Bydgoszcz was conducted in 2008-2016 throughout the flowering period of this plant. In 2016, insect pollinators of B. dioica flowers were also recorded in the city of Poznań. Bee species that could not be identified alive in the field were caught and identified in the laboratory.

Observations of the abundance and daily/seasonal activity of Andrena florea took place in 2012 and 2013 (ZYŚ 2014) at three study sites in the centre of Bydgoszcz:

Site 1: A sunny area in front of the Institute of Environmental Biology, Kazimierz Wielki University. There, Bryonia dioica grows on shrubs in a belt about $20 \mathrm{~m}$ long and climbs to a height of $3 \mathrm{~m}$. This microhabitat is favourable to both plant and insect.

Site 2: An urban park (Park Ludowy im. Wincentego Witosa). B. dioica grows on a fence about $25 \mathrm{~m}$ long and $2 \mathrm{~m}$ high. The microhabitat conditions are intermediate between sites 1 and 3 .

Site 3: The Botanical Garden of Kazimierz Wielki University. B. dioica grows on a low and spreading shrub of Taxus baccata, about $3 \mathrm{~m}$ long and $1.5 \mathrm{~m}$ tall. This microhabitat is unfavourable, as it is shaded and the humidity is high. This specimen of Bryonia dioica is markedly smaller than at sites 1 and 2 .

Two methods were used to estimate bee abundance: a quick assessment in 2012 on a $5 \mathrm{~m}^{2}$ patch, and a more detailed assessment in 2013 along a linear transect $100 \mathrm{~m}$ long and $1 \mathrm{~m}$ wide. The flower-visiting activity of Andrena florea was observed for 18 days during the flowering season, starting from 07:00 hrs and repeated every two hours until 17:00 hrs. Seasonal changes in activity were observed for 13 days during the flowering period of Bryonia dioica at every site. Observations of bee abundance and daily/seasonal dynamics 
were made on both warm, sunny days when the air temperature during sampling was $\geq 25^{\circ} \mathrm{C}$, and on cooler, cloudy days (sometimes with rain) when the air temperature was $\leq 18^{\circ} \mathrm{C}$. Temperature and precipitation data were extracted from ICM UW weather maps (Interdisciplinary Centre for Mathematical and Computational Modelling, University of Warsaw - mapy.meteo.pl).

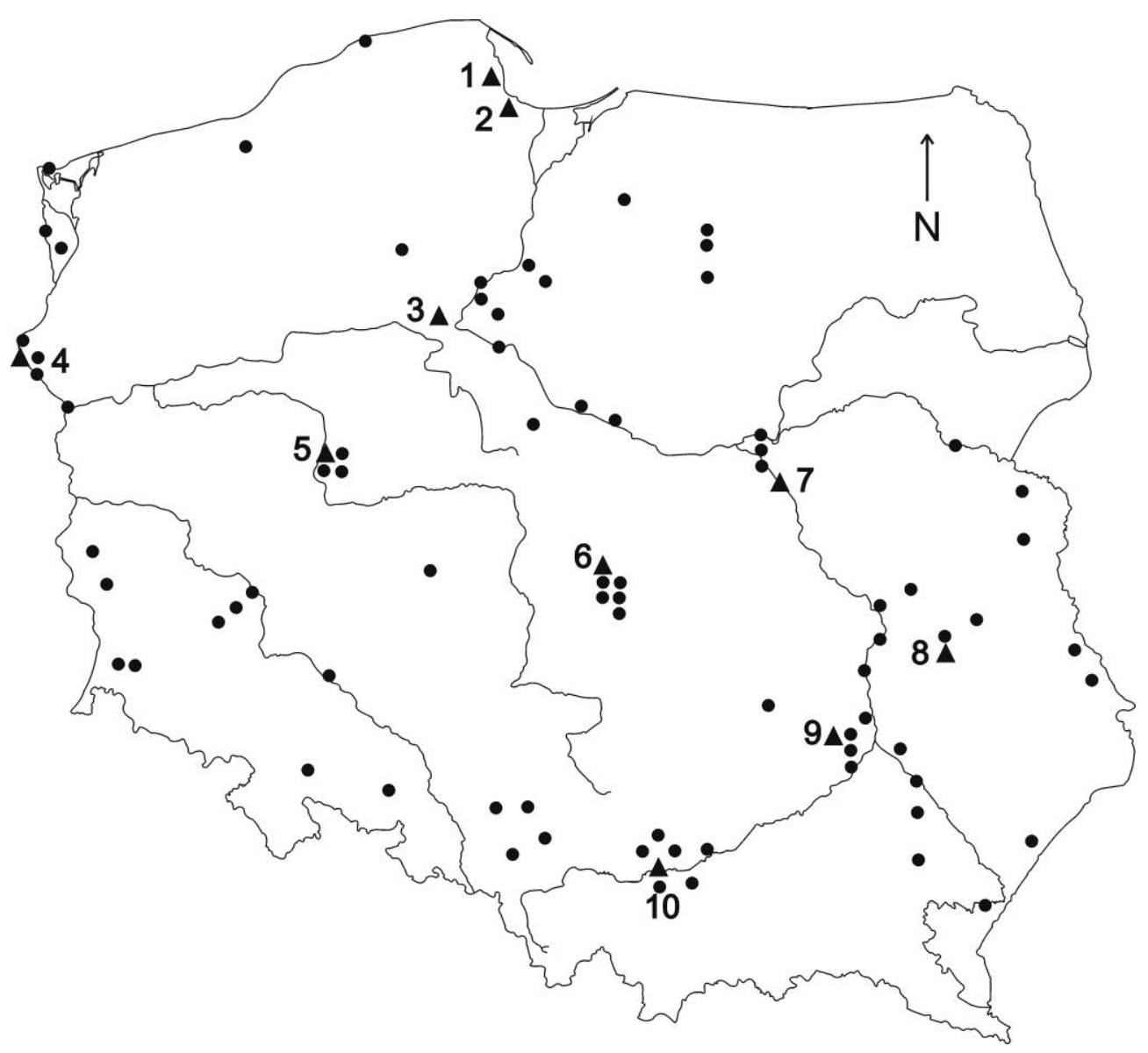

Fig. 1. Distribution of Bryonia dioica and Andrena florea in Poland. - Bryonia dioica; ム Andrena florea; 1 - Gdynia, 2 - Gdańsk, 3 - Bydgoszcz, 4 - Cedynia, 5 - Poznań, 6 - Łódź, 7 - Warszawa, 8 - Lublin, 9 - Opatów, 10 - Kraków. Study area: 3 - Bydgoszcz, 5 - Poznań. 


\section{RESULTS}

\section{Analysis of the spread of Andrena florea in Poland}

Before the year 2000, the species was recorded in Poland in only three regions: the Masurian Lakeland (BRISCHKE 1888), Silesia (Wrocław) (DITRICH 1903) - DITRICH mentioned this species from Silesia for the first time in 1889 as a new species for this region (DITRICH 1889), and the Kraków-Wieluń Upland (Kraków) (ŁOZIŃSKI 1920).

After 2000, the species was recorded in different urban areas: in Łódź (Mazovian Lowland) (KowALCZYK et al. 2004), Lublin (Lublin Upland) (unpubl. data; leg. H. RATYŃSKA), Poznań (Wielkopolska-Kujawy Lowland) (BANASZAK-CIBICKA \& ŻMIHORSKI 2012), Bydgoszcz (unpubl. data; leg. J. BANASZAK 2008-2016), as well as Cedynia (unpubl. data; leg. L. TWERD 2014), Gdynia (KowALCZYK \& TWERD 2011) and Gdańsk (all Pomeranian Lakeland) (unpubl. data; leg. W. BANASZAK-CiBICKA 2016) (Fig. 1).

\section{Analysis of the spread of Andrena florea in Bydgoszcz}

A. florea was observed in Bydgoszcz for the first time in 2008, at the site in front of the Institute of Environmental Biology. Then, the first author of this paper noted numerous, even abundant specimens of $A$. florea visiting the flowers of Bryonia dioica. This was the inspiration behind the research on the distribution of $B$. dioica and its bee pollinators.

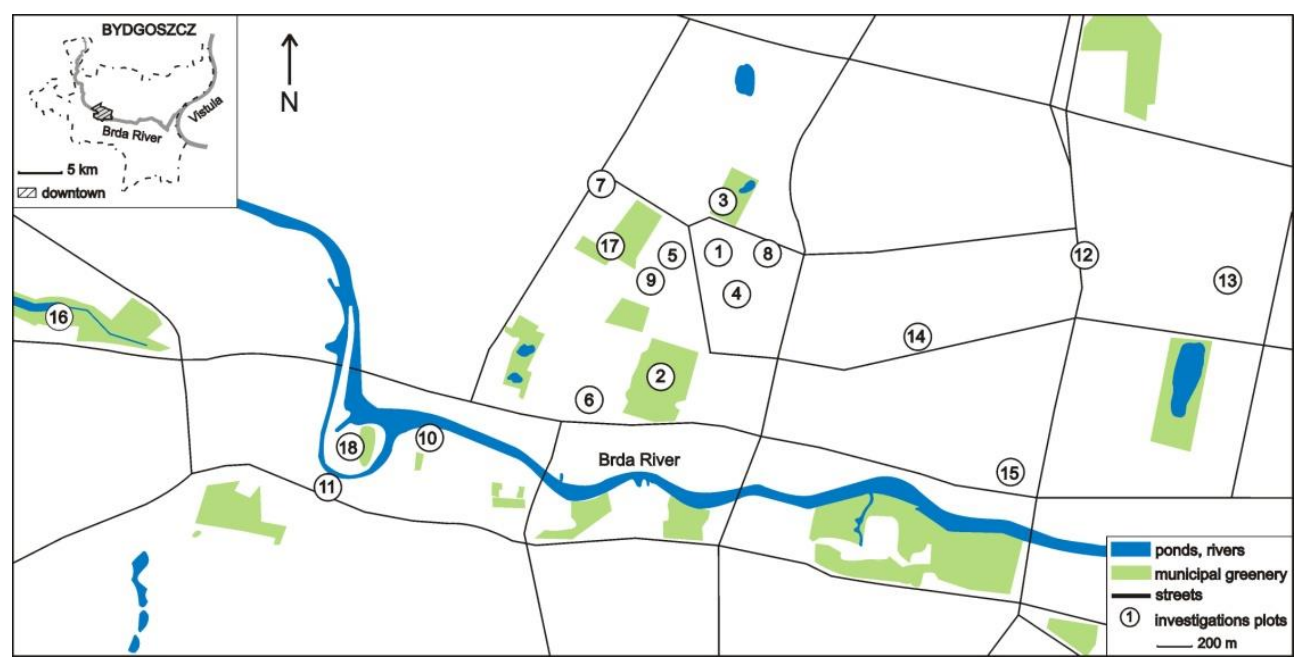

Fig. 2. Localities of Bryonia dioica and Andrena florea in Bydgoszcz. For detailed information about the position of the sites, see the Table 1. 
In 2008-2016 another 18 localities of $B$. dioica were discovered; consequently, there were 18 localities of Andrena florea in both the city centre and the suburbs (Fig. 2, Table $1)$.

Table 1. Localities of Bryonia dioica and Andrena florea in Bydgoszcz.

\begin{tabular}{|c|c|c|}
\hline Sites & Street/parks & Coordinates \\
\hline 1 & Ossolińskich - Institute of Environmental Biology & $\mathrm{N}: 53^{\circ} 07^{\prime} 45.29^{\prime \prime} ; \mathrm{E}: 18^{\circ} 00^{\prime} 58.13^{\prime \prime}$ \\
\hline 2 & Markwarta - Park Ludowy im. Wincentego Witosa & $\mathrm{N}: 53^{\circ} 07^{\prime} 29.64^{\prime \prime} ; \mathrm{E}: 18^{\circ} 00^{\prime} 49.06^{\prime \prime}$ \\
\hline 3 & Botanical Garden of Kazimierz Wielki University & N:5307'50.93"; E:18º1'03.93" \\
\hline 4 & Szymanowskiego & $\mathrm{N}: 53^{\circ} 07^{\prime} 39.41^{\prime \prime} ; \mathrm{E}: 18^{\circ} 01^{\prime} 04.20^{\prime \prime}$ \\
\hline 5 & Asnyka & $\mathrm{N}: 53^{\circ} 07^{\prime} 45.22^{\prime \prime} ; \mathrm{E}: 18^{\circ} 00^{\prime} 51.67^{\prime \prime}$ \\
\hline 6 & 3 Maja & $\mathrm{N}: 53^{\circ} 07^{\prime 2} 28.13^{\prime \prime} ; \mathrm{E}: 18^{\circ} 00^{\prime} 32.03^{\prime \prime}$ \\
\hline 7 & Mickiewicza /Gdańska & $\mathrm{N}: 53^{\circ} 07^{\prime} 54.63^{\prime \prime} ; \mathrm{E}: 18^{\circ} 00^{\prime} 36.03^{\prime \prime}$ \\
\hline 8 & Powstańców Wielkopolskich & $\mathrm{N}: 53^{\circ} 07^{\prime} 45.29^{\prime \prime} ; \mathrm{E}: 18^{\circ} 01^{\prime} 13.57^{\prime \prime}$ \\
\hline 9 & Kopernika & $\mathrm{N}: 53^{\circ} 07^{\prime} 42.85^{\prime \prime} ; \mathrm{E}: 18^{\circ} 00^{\prime} 46.15^{\prime \prime}$ \\
\hline 10 & Mostowa & N:5307'22.47"; E:1759'59.35" \\
\hline 11 & Mennica - Wyspa Młyńska & N:5307'17.19"; E:1759'41.12" \\
\hline 12 & Wyszyńskiego/Powstańców Wielkopolskich & $\mathrm{N}: 53^{\circ} 07^{\prime} 45.09^{\prime \prime} ; \mathrm{E}: 18^{\circ} 02^{\prime} 15.77^{\prime \prime}$ \\
\hline 13 & Połczyńska & $\mathrm{N}: 53^{\circ} 07^{\prime} 41.80^{\prime \prime} ; \mathrm{E}: 18^{\circ} 02^{\prime} 46.52^{\prime \prime}$ \\
\hline 14 & Curie Skłodowskiej & N:5307'34.15"; E:18º1'47.19" \\
\hline 15 & Jagiellońska & $\mathrm{N}: 53^{\circ} 07^{\prime} 16.43^{\prime \prime} ; \mathrm{E}: 18^{\circ} 02^{\prime} 03.09^{\prime \prime}$ \\
\hline 16 & Nakielska & N:530'ㄴ.35"; E:1758'42.53" \\
\hline 17 & Paderewskiego - Park im. Jana Kochanowskiego & $\mathrm{N}: 53^{\circ} 07^{\prime} 45.92^{\prime \prime} ; \mathrm{E}: 18^{\circ} 00^{\prime} 37.67^{\prime \prime}$ \\
\hline 18 & Wyspa Młyńska & $\mathrm{N}: 53^{\circ} 07^{\prime 2} 21.25^{\prime \prime} ; \mathrm{E}: 17^{\circ} 59^{\prime} 44.68^{\prime \prime}$ \\
\hline
\end{tabular}

\section{Species composition of bees visiting Bryonia dioica}

A total of 27 bee species visiting flowers of $B$. dioica were recorded in Bydgoszcz and Poznań (Table 2). This plant was most frequently visited by Apis mellifera as well as Andrena florea and Evylaeus morio, for which B. dioica was a rich source of food. Other species of Apiformes were observed sporadically (Table 2). 
Table 2. Species of bees visiting flowers of Bryonia dioica (data from Bydgoszcz and Poznań).

\begin{tabular}{|c|c|c|c|}
\hline Species & Abundance & Sociality & Pollen specificity \\
\hline Hylaeus confusus NYLANDER, 1852 & 1 & $\mathrm{~S}$ & $\mathrm{P}$ \\
\hline Hylaeus hyalinatus SмIтH, 1842 & 2 & S & $\mathrm{P}$ \\
\hline Andrena florea FABRICIUS, 1793 & 70 & S & $\mathrm{O}$ \\
\hline Andrena nigroaenea (KIRBY, 1802) & 2 & S & $\mathrm{P}$ \\
\hline Andrena nitida (MÜLLER, 1776) & 1 & S & $\mathrm{P}$ \\
\hline Halictus rubicundus (CHRIST, 1791) & 7 & $\mathrm{E}$ & $\mathrm{P}$ \\
\hline Seladonia tumulorum (LINNNAEUS, 1758) & 5 & $\mathrm{E}$ & $\mathrm{P}$ \\
\hline Lasioglossum sexnotatum (KIRBY, 1802) & 5 & S & $\mathrm{P}$ \\
\hline Evylaeus albipes (FABRICIUS, 1781) & 6 & $\mathrm{E}$ & $\mathrm{P}$ \\
\hline Evylaeus brevicornis (SCHENCK, 1863) & 3 & E & $\mathrm{P}$ \\
\hline Evylaeus calceatus (SCOPOLI, 1763) & 2 & $\mathrm{E}$ & $\mathrm{P}$ \\
\hline Evylaeus laticeps (SCHENCK, 1868) & 2 & $\mathrm{E}$ & $\mathrm{P}$ \\
\hline Evylaeus morio (FABRICIUS, 1793) & 50 & $\mathrm{E}$ & $\mathrm{P}$ \\
\hline Evylaeus nitidulus (FABRICIUS, 1804) & 2 & $\mathrm{E}$ & $\mathrm{P}$ \\
\hline Evylaeus pauxillus (SCHENCK, 1853) & 1 & $\mathrm{E}$ & $\mathrm{P}$ \\
\hline Evylaeus sexstrigatus (SCHENCK, 1868) & 7 & S & $\mathrm{P}$ \\
\hline Osmia rufa (LINNAEUS, 1758) & 3 & S & $\mathrm{P}$ \\
\hline Megachile versicolor SMITH, 1844 & 1 & $S$ & $\mathrm{P}$ \\
\hline Megachile willughbiella (KIRBY, 1802) & 1 & $\mathrm{~S}$ & $\mathrm{P}$ \\
\hline Anthophora plumipes (PALLAS, 1772) & 3 & $\mathrm{~S}$ & $\mathrm{P}$ \\
\hline Nomada moeschleri ALFKEN, 1913 & 2 & $\mathrm{CP}$ & {$[\mathrm{P}]$} \\
\hline Bombus hypnorum (LINNAEUS, 1758) & 6 & $\mathrm{E}$ & $\mathrm{P}$ \\
\hline Bombus lapidarius (LiNNAEUS, 1758) & 2 & $\mathrm{E}$ & $\mathrm{P}$ \\
\hline Bombus muscorum (LINNAEUs, 1758) & 1 & $\mathrm{E}$ & $\mathrm{P}$ \\
\hline Bombus pascuorum (SCOPOLI, 1763) & 6 & $\mathrm{E}$ & $\mathrm{P}$ \\
\hline Bombus pratorum (LINNAEUS, 1761) & 2 & $\mathrm{E}$ & $\mathrm{P}$ \\
\hline Apis mellifera LINNAEUS, 1758 & 85 & $\mathrm{E}$ & $\mathrm{P}$ \\
\hline
\end{tabular}

Abundance: total number of specimens collected across all sites and all years. $\%$ of individuals: percentage of total collection identified as this species $(n=2495)$. Pollen specificity: classification as either polylectic (collecting pollen from multiple plant families) or oligolectic (collecting pollen from a single plant family or genus); $[\mathrm{P}]$ indicates parasitic species that do not collect pollen. Sociality: classification as either $\mathrm{E}$ - eusocial, $\mathrm{CP}$ - cleptoparasitic, $\mathrm{S}$ - solitary. 


\section{Daily activity}

The daily activity of Andrena florea lasted from 08:00 or 09:00 hrs until 15:00 or 17:00 hrs, depending on the temperature and insolation (Fig. 3).
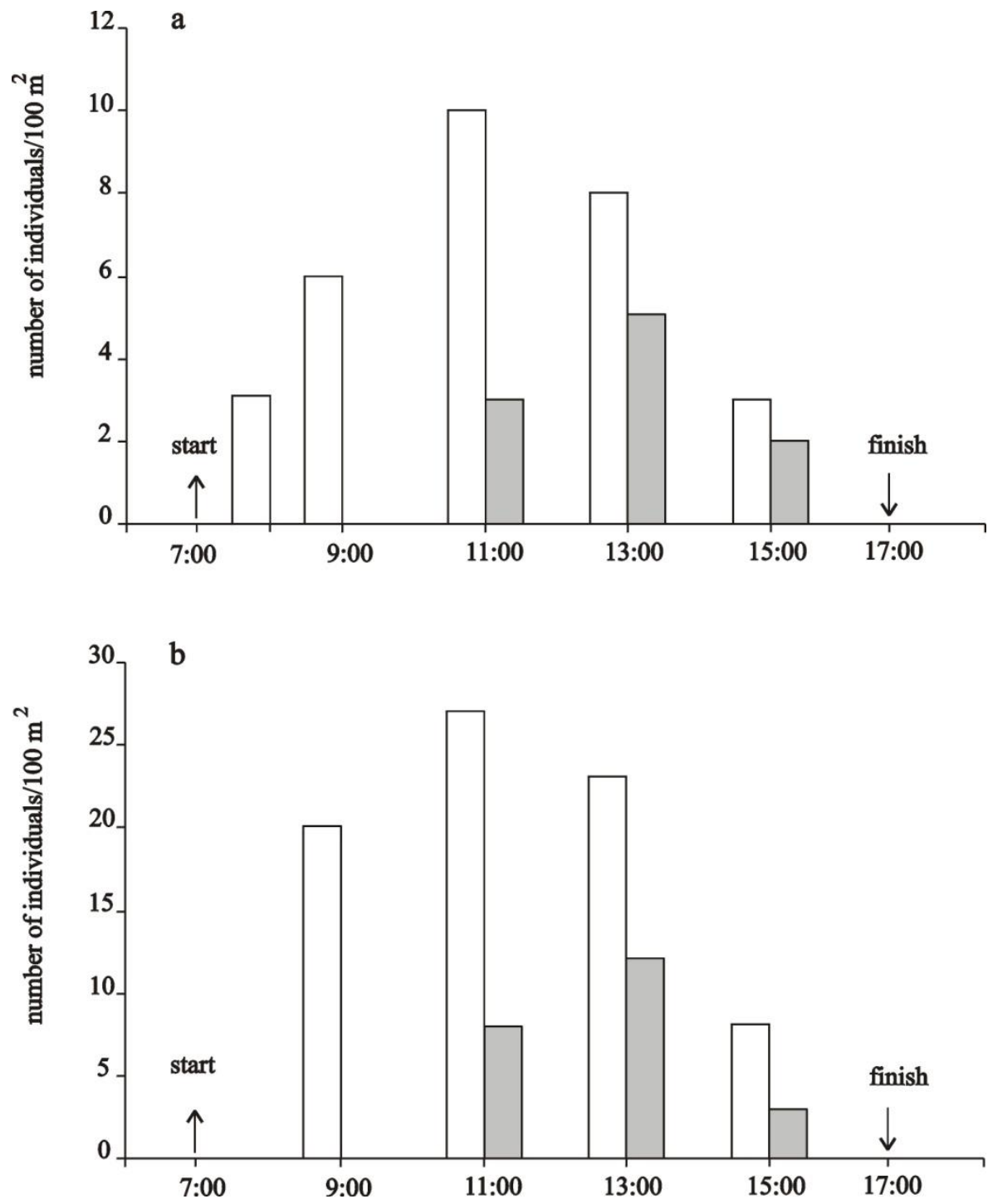

Fig. 3. Daily dynamics of Andrena florea at site 1 (a) in 2012; and (b) in 2013. Number of individuals: sunny weather - air temperature during sampling $\geq 25^{\circ} \mathrm{C}$ (white), cloudy weather - temperature $\leq 18^{\circ} \mathrm{C}$ (grey). 
On warm and sunny days with higher temperatures, the first bees were observed around 08:00 hrs; on colder days they started to appear later, i.e. after 09:00 hrs. On warm and sunny days this activity peaked around 11:00 hrs, after which the number of bees dropped; after 15:00 hrs only a few worker bees were noted. On colder days, activity peaked later, around 13:00 hrs; there were fewer bees, and they ended their visits to Bryonia dioica earlier. The bees were active for about 8 hours on warm days and around 6 hours on cooler days (Fig. 3).

\section{Seasonal dynamics}

The seasonal flight dynamics of Andrena florea were similar in both years. In 2012, the first specimens were recorded on 15 May, whereas in 2013, they first arrived on 19 May. They appeared the earliest at site 1 (in front of the Institute of Environmental Biology), and the latest (2-3 days later) at site 3 (in the Botanical Garden). The highest density of $A$. florea during the season was recorded from 25 May onwards at site 1, and slightly later, after 29 May, at site 2. At site 3 the density curve of this species was very different: it did not peak until after 6 June. From the beginning of July, the bees' activity gradually declined at all the sites, and after 15 July no more specimens of $A$. florea were recorded. The seasonal flight dynamics of Andrena florea in 2013 are presented on Fig. 4.

\section{DISCUSSION}

Analysis of the relationships between the pollinator and the bee forage plant revealed a positive association between the occurrence of Bryonia dioica and the presence of Andrena florea. The distributions of both species overlap, covering western Europe as far as England and Denmark in the north (SCHRÖDER \& LUNAU 2001, VOLTZ 2008). The relationships are conspicuous on both the national and local scale. Until recently, Andrena florea was regarded as rare and threatened in Poland. The present results indicate that populations of A. florea appear in urban areas as soon as Bryonia dioica spreads there. Although the majority of bee species are polylectic, collecting pollen from plants of different families, oligolectic bees restrict their pollen gathering to plant species from the same genus. Andrena florea is one such oligolectic species, associated with the genus Bryonia, so its distribution is strongly linked with the distribution of its forage plant. Moreover, Andrena florea is reproductively dependent on Bryonia. A narrow foraging niche may suggest a higher vulnerability of this species to disturbance, e.g. declines of its food sources (KLEIJN \& RAEMAKERS 2008). The plant species, on the other hand, does not depend on this specialized bee, as its reproductive success is guaranteed by other, polylectic visitors to its flowers. 

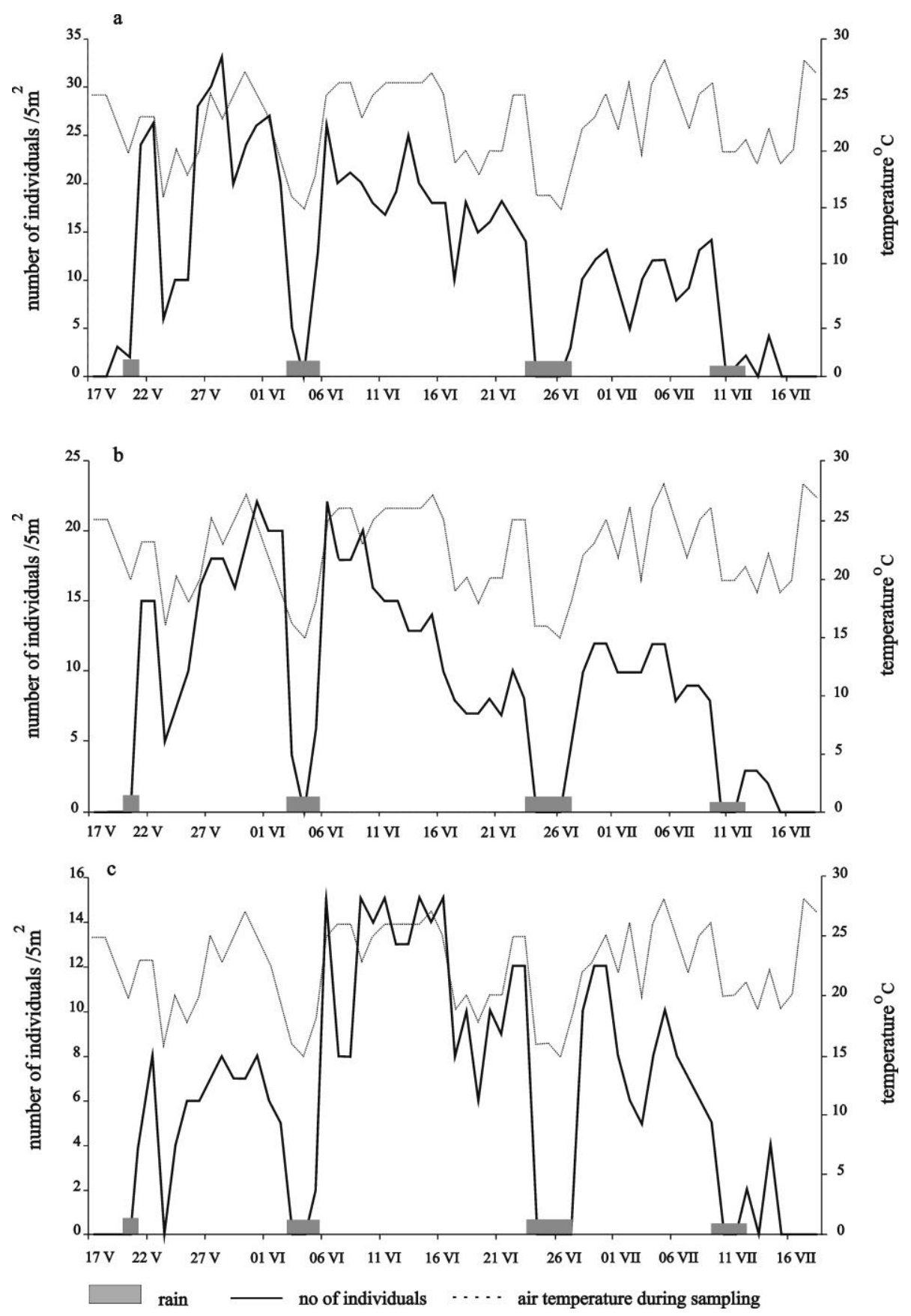

Fig. 4. Intensity of visits of wild bees on Bryonia dioica in 2013: (a) at site 1; (b) at site 2; (c) at site 3 . 
Analysis of the contribution of Apiformes to the pollination of Bryonia dioica indicated that three bee species played a major role in this process: Apis mellifera, Andrena florea and Evylaeus morio; the contributions of 24 other bee species visiting the flowers were smaller (Table 2). Hence, the present data emphasize the part played by this invasive climber as a bee forage plant: while enabling the survival of the bee species obligatorily associated with it, it is also important for many other wild bee species and for the honey bee (Apis mellifera was often abundant on flowers of Bryonia dioica).

Neither the Nature Conservation Act of 2004 (sect. 5, paragraph 1 c, sect. 120, sect. 120, sect. 130, sect. 131), nor the Regulation of the Minister of Environmental Protection of 9 October 2011 listing alien plants and animals (which - if introduced to the natural environment - may pose a threat to native species and habitats) to date include both Bryonia alba and B. dioica. They are not regarded as particularly invasive but are locally common (especially $B$. alba) and may endanger native ecosystems. This is evidenced by the fact that $B$. alba already forms its own tall-herb community, first described in the Lublin region by FIJAŁKOWSKI (1978). Patches of Sicyo-Echinocystietum compete with native riparian tall-herb fringe communities, representative of a protected habitat type (6430). RATYŃSKA et al. (2010) regard them as a very expansive, xenospontaneous community, spreading especially along river valleys. The expansion of Bryonia dioica has also been confirmed by a number of authors from Germany (SCHRÖDER \& LUNAU 2001, CADOUM \& Didier 2008, VenNe 2015, AYASSE et al. 2015) and Austria (ZetTel et al. 2013).

The present observations indicate that there are many sites of $B$. dioica in cities, and consequently, of large and stable local populations of Andrena florea. Warmer urban climates provide living conditions appropriate for plant and bee species from western and southern Europe. The last 8 years have witnessed the expansion of this climber in Bydgoszcz and the resultant spread of this bee species, which was rare until recently. It is noteworthy that Professor Wilhelm Bock, in his Taschenflora von Bromberg published in 1908, listed Bryonia alba but not B. dioica among the 1256 plant species from Bydgoszcz and its environs. Another German botanist from the Poznań region likewise listed only $B$. alba (SPRIBILLe 1887). At present, B. dioica is colonizing new areas in Poznan, too (currently recorded at 3 sites), which has resulted in the large-scale occurrence of Andrena florea (observations in 2007-2016 (BANASZAK-CIBICKA unpubl. data)). In comparison, JACKOWIAK (1990) reported this species from only two sites in the same city. Recent research has shown Bryonia dioica to be present in botanical gardens in many Polish cities - Bydgoszcz, Łódź, Poznań, Kraków, Lublin, Wrocław and Warsaw (also the botanical garden in Powsin, in the suburbs of Warsaw) (GALERA 2003).

Analysis of the relationships between the presence and flowering of B. dioica, environmental conditions and the occurrence of bee species showed the density of Andrena florea to be the highest at sites with favourable microclimatic conditions, i.e. in open, sunny 
habitats. At shaded sites, both its flowering and the subsequent visits of bees started later. These results indicate that both species preferred sunny sites and favourable temperatures. Urban ecosystems undoubtedly create such favourable conditions for expansion. For years, many authors (SUDNIK-WÓJCIKOWSKA 1998a, 1998b, BANASZAK-CIBICKA 2014) have reported that for both plants and animals, conurbations constitute heat islands with higher temperatures, lower humidity and, obviously, higher levels of pollution. This is reflected by the presence of so-called urbanophilous species, which achieve their optimum in such conditions, and in the markedly earlier beginning of the growing season than in surrounding areas (ROETZER et al. 2000, WHITE et al. 2002). For many groups of animals, the warmer and drier urban microclimate produces suitable living conditions for thermophilous and xerophilous species originating from southern Europe (BANASZAK-CIBICKA 2014). As a result of these higher temperatures and the accessibility of bee forage plants, cities can support not only widespread species but also some rare ones with specific requirements, like A. florea. This southern bee species is more sensitive to low temperatures. This relationship is also manifest in the dynamics of the activity of this bee. The present results show that even a small drop in air temperature leads to a noticeable decline in bee densities and can even bring bee visits to a halt.

Since 2013, the German "Wildbiene des Jahres" project (AYASSE et al. 2015) has selected a "Bee of the Year" in order to popularize knowledge about wild bees and to show that these extremely beneficial insects are threatened. In the scientific sense, this initiative explains the distribution of the bee of the year and encourages people to search for it in their environment. The bee of 2015 was A. florea, obligatorily associated with B. dioica, whose fate is ultimately dependent on sufficient resources of this plant. Such interactions between alien and native species complicates environment management. Alien plant species are not only an additional source of food for local pollinators (FRANKIE et al. 2005) but also enable the spread of insect species obligatorily associated with them, such as bees. Control of the invader, even if justified for other reasons, could lead to the extinction of a rare indigenous species. Our research has demonstrated that at present neither the bee nor the climber are threatened in Poland and are tending to spread. However, since Bryonia dioica is alien, whereas A. florea was until recently regarded as rare and threatened in Poland, it is important to monitor the expansion of this bee forage plant in both cities and suburban areas, and to assess changes in populations of Andrena florea.

\section{REFERENCES}

Ayasse M., Klatt M., Krotochwil A., Krogmann L., Schwenniger H.R. 2015 Wildbiene des Jahres 2015. Die Zaunrüben-Sandbiene. Trennkost bevorzugt. Internet: http://www.wildbienenkataster.de/login/downloads/wb2015.pdf (accessed 25 August 2016) 
Banaszak J. 2004. Bees (Apidae). [in:] W. Bogdanowicz, E. Chudzicka, J. Pilipiuk, E. SkibińSka (eds.). Fauna of Poland. Characteristics and checklist of species, vol. 1. Muzeum i Instytut Zoologii PAN, Warszawa, 346-350. (in Polish)

BANASZAK-CIBICKA W. 2014. Are urban areas suitable for thermophilic and xerothermic bee species (Hymenoptera: Apoidea: Apiformes)? Apidologie, 45 (2): 145-155.

BANASZAK-CIBICKA W., ŻMIHORSKI M. 2012. Wild bees along an urban gradient: winners \& losers. Journal of Insect Conservation, 16 (3): 331-343.

Bartomeus I., VilŔ M., Santamaría L. 2008. Contrasting effects of invasive plants in plantpollinator networks. Oecologia, 155 (4): 761-70.

Bax N., Williamson A., Aguero M., GonZalea E., Geeves W. 2003. Marine invasive alien species: a threat to global biodiversity. Marine Policy, 27 (4): 313-323.

Bock W. 1908. Taschenflora von Bromberg. Tabellen zur Bestimmung der Gefäßpflanzen des Regierungsbezirks Bromberg nebst Standortsangaben; zum Gebrauche auf Ausflügen, in Schulen und zum Selbstunterricht. Mittler'sche Buchhandlung (A. Fromm Nachf.), Bromberg.

BRISChKe C.G.A. 1888. Hymenoptera aculeata der Provinzen West- und Ostpreussen. Schriften der Naturforschenden Gesellschaft in Danzig, N.F., 7: 85-107.

CADOum S., DiDiER B. 2008. Andrena florea et la bryone. Insectes, 150: 3-4.

DAVIS M.A. 2009. Invasion biology. Oxford University Press, Oxford.

DitRICH R. 1889. Andrena florea neu für Schlesien. Zeitschrift fur Entomologie, 14: XXI.

DitRICH R. 1903. Verzeichnis der bisher in Schlesien aufgefundenen Hymenopteren. I. Apidae. Zeitschrift für Entomologie N.F., 20: 21-54.

Dudek K., Michlewicz M., Dudek M., Tryjanowski P. 2016. Invasive Canadian goldenrod (Solidago canadensis L.) as a preferred foraging habitat for spiders. Arthropod-Plant Interactions, 10 (5): $377-381$.

Ewel J.J., O‘Dowd D.J., Bergelson J., DAehler C.C., D‘Antonio C.M. Gómez L.D., Gordon D.R., Hobbs R.J, Holt A., Hopper H.R., Hughes C.E., LaHart M., LeAKey R.R.B., LeE W.G., Loope L.L., LoRence D.H., Louda S.M., Lugo A.E., McEvoy P.B., RichardSON D.M., VitouseK P.M. 1999. Deliberate introductions of species: research needs. BioScience, 49 (8): 619-630.

FIJAŁKOWSKI D. 1978. Synanthropic plants in the Lublin region. PWN, Warszawa - Łódź. (in Polish)

Frankie G.W., Thorp R.W., Schindler M., Hernandez J., Ertter B., Rizzardi M. 2005. Ecological patterns of bees and their host ornamental flowers in two northern California cities. Journal of Kansas Entomological Society, 78 (3): 227-246.

GALeRA H. 2003. Plants occurring spontaneously in Polish botanical gardens. Biuletyn Ogrodów Botanicznych, 12: 31-82. (in Polish)

Goodenough A. 2010. Are the ecological impacts of alien species misrepresented? A review of the "native good, alien bad" philosophy. Community Ecology, 11 (1): 13-21.

Gusenleitner F., Schwarz M. 2002. Weltweite Checkliste der Bienengattung Andrena mit Bemerkungen und Ergänzungen zu paläarktischen Arten. Entomofauna, Suppl. 12: 1-1280. 
JACKOWIAK B. 1990. Anthropogenic changes of flora of vascular plants in Poznań. Wydawnictwo Naukowe Uniwersytetu im. Adama Mickiewicza, Poznań. (in Polish)

KLEIJN D., RAEMAKerS I. 2008. A retrospective analysis of pollen host plant use by stable and declining bumblebee species. Ecology, 89 (7): 1811-1823.

Kocourek M. 1989. Enumeratio insectorum Bohemoslovakiae, Check list of Czechoslovak Insects III (Hymenoptera, Apoidea). Acta Faunistica Entomolica Musei Nationalis Pragae, 19: 173-184.

KowalcZyk J.K., SzCZEPKo K., KuRZAC T., PAwlikowski T. 2004. Bees (Hymenoptera, Apoidea) of the Botanical Garden in Łódź. [in:] P. Indykiewicz, T. BARTCZAK (eds.) Fauna miast Europy Środkowej 21. wieku. Wydawnictwo LOGO, Bydgoszcz, 67-82. (in Polish)

KowalCZYK J.K., Twerd L. 2011. Aculeata and other interesting insects of empty land in the city of Gdynia (Poland). [in:] P. Indykiewicz, L. JerzaK, J. BöHNER, B. KAVANAGH (eds.) Urban fauna. Studies of animal biology, ecology and conservation in European cities. University of Technology and Life Sciences in Bydgoszcz, Bydgoszcz, 261-267.

Levine J.M., VilÀ M., D’Antonio C.M., Dukes J.S., Grigulis K., LAVorel S. 2003. Mechanisms underlying the impacts of exotic plant invasions. Proceedings of the Royal Society (London) B, 270 (1517): 775-781.

LIPIŃSKI M. 2010. Bees` forage plants. PWRiL, Warszawa, Wydawnictwo Sądecki Bartnik, Stróże. (in Polish)

ŁoZIŃSKI P. 1920. Hymenoptera in Cracow area. Sprawozdania Komisji Fizjograficznej Polskiej Akademii Umiejętności, 53/54: 125-137. (in Polish)

Matteson K.C., Ascher J.S., LANGellotto G.A. 2008. Bee richness and abundance in New York City urban gardens. Annals of the Entomological Society of America, 101 (1): 140-150.

Montero-CASTAŃO A., VilÁ M. 2012. Impact of landscape alteration and invasions on pollinators: a meta-analysis. Journal of Ecology, 100 (4): 884-893.

Moroń D., Lenda M., Skórka P., Szentgyorgyi H., Settele J., Woyciechowski M. 2009. Wild pollinator communities are negatively affected by invasion of alien goldenrods in grassland landscapes. Biological Conservation, 142 (7): 1322-1332.

PiSANTY G., MANDELIK Y. 2012. Effects of alien species on plant-pollinator interactions: how can native plants adapt to changing pollination regimes? Evolution of Plant-Pollinator Relationships, 15: 414-438.

RATYŃSKa H., Wojterska M., BrZEG A., KoŁACZ M. 2010. A multimedia encyclopedia of plant communities in Poland. NFOŚiGW, Warsaw, 400: 1-2. (in Polish)

RENNER S.S., SCHAefer H. 2008. Phylogenetics of Cucumis (Cucurbitaceae) as understood in 2008. [in:] M. PITRAT (ed.). Cucurbitaceae 2008. Proceedings of the IXth EUCARPIA Meeting on Genetics and Breeding of Cucurbitaceae. INRA, Avignon, 53-58.

Roetzer T., Wittenzeller M., Haeckel H., Nekovar J. 2000. Phenology in central Europe differences and trends of spring phenophases in urban and rural areas. International Journal of Biometeorology, 44 (2): 60-66.

SANTAMOURIS M. (ed.) 2013. Energy and climate in the urban built environment. Routledge, Abingdon. 
SCHRÖDER S., LunAu K. 2001. Die oligolektische Sandbiene Andrena florea und die Rote Zaunrübe Bryonia dioica - Schnittstelle zweier spezialisierter Fortpflanzungssysteme. Mitteilungen der Deutschen Gesellschaft für Allgemeine und Angewandte Entomologie, 13: 529-533.

SPRIBILle F. 1887. Verzeichnis der Standorte der seltenerer Pflanzen des Kreises Szubin. Festschrift zum fünfzigjährigen Jubiläum des Naturwissenschaftlichen Vereins der Provinz Posen 1837 bis 1887. E. Schmaedicke's Buchdruckerei, Posen, 17-32.

SUDNIK-WÓJCIKOWSKA B. 1998a. Time and spatial aspects of the process of synanthropization of flora on the example of selected cities in Central Europe. Wydawnictwo Uniwersytetu Warszawskiego, Warszawa. (in Polish)

SudNiK-WÓJCIKOWSKA B. 1998b. The effect of temperature on the spatial diversity of urban flora. Phytocoenosis 10 (N.S.) Supplementum Cartographiae Geobotanicae, 9: 97-105

SUDNIK-WÓJCIKOWSKA B., KoŹNIEWSKA B. 1988. Dictionary in the field of synanthropization of plant cover. Wydawnictwo Uniwersytetu Warszawskiego, Warszawa. (in Polish)

The Nature Conservation Act of 16 April 2004. Dziennik Ustaw, nr 92, poz. 880.

The Regulation of the Minister of Environmental Protection of 9 October 2011. Dziennik Ustaw, nr 210, poz. 1260.

Tokarska-GuZik B., Dajdok Z., Zając M., Zając A., Urbisz A., Danielewicz W., Holdyński C. 2012. Alien plants in Poland, with particular reference to invasive species. Generalna Dyrekcja Ochrony Środowiska, Warszawa. (in Polish)

Traveset A., Richardson D.M. 2006. Biological invasions as disruptors of plant reproductive mutualisms. Trends Ecology \& Evolution, 21 (4): 208-216.

VENNE CH. 2015. Die Zaunrüben-Sandbiene (Andrena florea). Wildbiene des Jahres 2015. Internet: http://www.bs-paderborn-senne.de/uploads/media/NATVM-2015-Venne-Sandbiene.pdf

Vilà M., Basnou C., Pyšek P., Josefsson M., Genovesi P., Gollasch S., Nentwig W., Olenin S., Roques A., Roy D., Hulme P.E. 2010. How well do we understand the impacts of alien species on ecosystem services? A pan-European cross-taxa assessment. Frontiers of Ecology and Environment, 8 (3): 135-144.

Volz S.M. 2008. Evolution of Dioecy in the Cucurbitaceae Genus Bryonia: A Phylogenetic, Phylogeographic, and SCAR-marker Approach. Dissertation, Ludwig Maximilian University of Munich.

White M.A., Nemani R.R., Thornton P.E., Running S.W. 2002. Satellite evidence of phenological differences between urbanized and rural areas of the eastern United States deciduous broadleaf forest. Ecosystems, 5 (3): 260-273.

ZAJĄC A., ZAJĄC M. 2001. Distribution Atlas of Vascular Plants in Poland. Pracownia Chorologii Komputerowej Instytutu Botaniki Uniwersytetu Jagiellońskiego, Kraków. (in Polish)

Zettel H., Zimmermann D., Wiesbauer H. 2013. Die Bienen und Grabwespen (Hymenoptera: Apoidea) im Donaupark in Wien (Österreich). Sabulosi, 3: 1-23. 
ZYŚ T. 2014. Seasonal and daily activity of Andrena florea. MSc thesis, Uniwersytet Kazimierza Wielkiego, Bydgoszcz. (in Polish)

Received: 23 February 2018

Accepted: 9 March 2018 